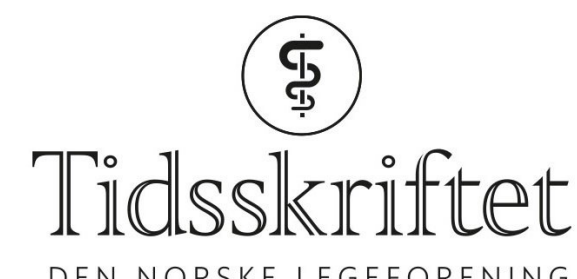

DEN NORSKE LEGEFORENING

\title{
Komplett om araknoidale cyster
}

ANMELDELSER

TOR INGEBRIGTSEN

Professor II, Institutt for klinisk medisin

Det helsevitenskapelige fakultet

Universitetet i Troms $\varnothing$ - Norges arktiske universitet
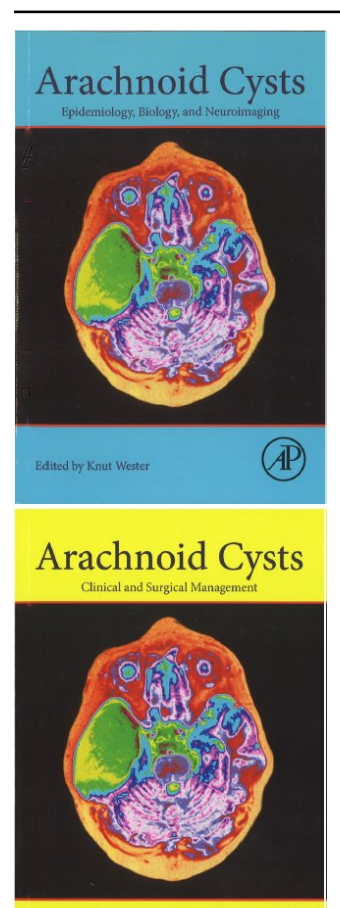

Ealded by Knat Neserer (AP)

Knut Wester, red.

Arachnoid cysts

Epidemiology, biology, and neuroimaging. 221 s, tab, ill. London: Academic Press, 2018. Pris GBP 79

ISBN 978-0-12-809932-2

Knut Wester, red.

Arachnoid cysts

Clinical and surgical management. 306 s, tab, ill. London: Academic Press, 2018. Pris GBP 100

ISBN 978-0-12-814378-0 
Intrakraniale araknoidale cyster er den romoppfyllende intrakraniale tilstanden som påvises hyppigst, ofte som tilfeldig funn ved billedundersøkelser. Tilstandens kliniske betydning er omdiskutert, og det er ikke publisert systematiske litteraturgjennomganger som sammenfatter kunnskapen om slike cyster. Det er derfor et ambisiøst prosjekt professor emeritus Knut Wester ved Universitetet i Bergen har påtatt seg ved å redigere et tobinds læreverk om tilstanden.

Bøkene henvender seg først og fremst til nevrologer, nevrokirurger, nevropsykologer, radiologer, barneleger og andre klinikere, men også forskere som arbeider med basale sykdomsmekanismer og patofysiologi kan ha nytte av bøkene.

Volum 1 omtaler biologiske aspekter, epidemiologi og billedundersøkelser. Kapitlene om historiske perspektiver er interessante og byr på til dels underholdende lesing. Volum 2 presenterer kunnskap fra klinisk forskning om araknoidale cyster som mulig årsak til vanlige plager som hodepine, svimmelhet, synsforstyrrelser og redusert kognitiv funksjon, samt en detaljert gjennomgang av aktuelle nevrokirurgiske behandlingsmetoder.

Kapittelforfatterne er rekruttert fra hele verden, men det nevrofaglige forskningsmiljøet ved Universitetet i Bergen, inklusive redaktøren selv, bidrar med hele 17 av bøkenes 36 kapitler. De fleste begynner med et kortfattet sammendrag av konklusjonene fra litteraturgjennomgangen som presenteres, sortert på evidensnivå (I-IV). Kunnskapsgrunnlaget preges av at de fleste publiserte kliniske studier er selekterte pasientserier, hvilket medfører at evidensnivået vanligvis er på III eller IV. Forfatterne trekker likevel klare konklusjoner og anbefaler kirurgisk behandling med nevroendoskopisk operasjon eller kraniotomi for pasienter med uttalte symptomer uten annen åpenbar årsak. Noen av anbefalingene vil nok være omdiskutert i fagmiljøene.

Kapitlene kan leses hver for seg som enkeltstående oversiktsartikler, men utgjør til sammen et komplett læreverk. Bøkene er rikelig illustrert med gode bilder og figurer. Kapitlene overlapper mer enn nødvendig, og det forekommer, som redaktøren selv påpeker i forordet, til dels motstridende tolkninger av kunnskapsgrunnlaget i de forskjellige kapitlene. Bøkene anbefales likevel som det sannsynligvis mest komplette tilgjengelige lære- og oppslagsverket om araknoidale cyster.

Publisert: 1. oktober 2018. Tidsskr Nor Legeforen. DOI:10.4045/tidsskr.18.0362

(C) Tidsskrift for Den norske legeforening 2020. Lastet ned fra tidsskriftet.no 